\title{
Supervision, support and professional development for newly qualified social workers in Aotearoa New Zealand
}

Liz Beddoe ${ }^{1}$, Neil Ballantyne ${ }^{2}$, Jane Maidment ${ }^{3}$, Kathryn Hay ${ }^{4}$ and Shayne Walker ${ }^{5}$

\begin{abstract}
INTRODUCTION: Many social work professional bodies and regulators mandate regular supervision and professional development. Supervision is believed to support continuing development of professional skills, safeguarding of competent and ethical practice, oversight of the practitioner's work for adherence to organisational expectations, and support for practitioner wellbeing.

METHOD: Phase two of the Enhancing the Readiness to Practice of Newly Qualified Social Workers (Enhance R2P) project employed a mixed methods study (surveys and interviews) to explore how well prepared newly qualified social workers (NQSWs) are, in their first two years of practice, to enter professional social work. A survey of managers/supervisors and NQSWs in Aotearoa New Zealand about the readiness to practise of recent graduates was conducted.
\end{abstract}

FINDINGS: Questions about supervision and professional development were included in the survey and in interviews with both NQSWs and supervisors/managers. Around half of NQSWs were supervised at least once every two weeks, but another half were supervised monthly or less frequently. Observation of practice by supervisors was either very infrequent or entirely absent from the professional development of NQSWs.

IMPLICATIONS: Study findings revealed great variability in the formal supervision and other supports available for NQSWs which may impact on retention and practitioner wellbeing. More integrated systems of supervision, peer support and planned professional development are needed.

KEYWORDS: Newly qualified social workers; supervision; professional development
${ }^{1}$ Liz Beddoe, University of Auckland, New Zealand

${ }^{2}$ Neil Ballantyne, Open Polytechnic of New Zealand

3 Jane Maidment, University of Canterbury, New Zealand

${ }^{4}$ Kathryn Hay, Massey University, New Zealand

5 Shayne Walker, University of Otago, Dunedin, New Zealand
Supervision is generally regarded as a core element in career-long competency and professional development for social workers and, as such, it is mandated by professional bodies. The authors have conducted a three-year study examining the social work education curriculum and readiness to practise (Ballantyne et al., 2019a, 2019b, 2019c) and this has included exploring the supervision and professional development experiences of NQSWs. Expectations of supervision begin during pre-service education for social workers in Aotearoa New Zealand. The programme recognition standards of the Social Workers Registration Board ([SWRB] 2018) require that a social work student undertaking field education should be supervised for at least one hour per week. Further mandates regarding supervision are in place in practice.
AOTEAROA

NEW ZEALAND SOCIAL WORK 32(2), 17-31.

CORRESPONDENCE TO: Liz Beddoe

e.beddoe@auckland.ac.nz 
The SWRB sets out its expectations of supervision stating that it should be undertaken by registered social workers in Aotearoa New Zealand at least monthly. The policy document states:

Professional supervision is one of the essential means to develop workers and ensure quality service provision. .... It is the direct practice, guidance and reflection provided by supervision that enhances professional development and supports competent, accountable and safe practice. (SWRB, 2018, p. 2)

Whilst this section does not mention anything regarding increased supervision frequency for NQSWs, it seems reasonable to assume that the monthly minimum is imperative for new graduates and that a higher frequency, perhaps at least once every two weeks, might be appropriate. The professional association, the Aotearoa New Zealand Association of Social Work (ANZASW) however, does recommend that, in the first year of practice, ANZASW members have a minimum of one-hour core social work supervision per week with a career-long expectation of a minimum of one hour per month (ANZASW, 2015, p. 3). Little is known about the extent to which these policies are implemented in social work in Aotearoa New Zealand, and even less that specifically relates to NQSWs. Neither policy makes reference to observation of practice as part of feedback.

In a recent survey conducted over 2014-2015, O'Donoghue (2019) asked about the frequency of registered social workers' supervision contact and revealed that slightly more than half $(56.2 \%, n=155)$ had monthly contact (p. 65). Over a fifth of respondents $(22.8 \%, \mathrm{n}=63)$ had fortnightly supervision. Overall, $88.4 \%(n=243)$ had supervision at least monthly or more. The 'other' category $(11.6 \%, n=32)$ revealed a range of experiences related to infrequent supervision which included from six-weekly and bimonthly, to very infrequently and rarely having supervision at all.
This study did not specifically address the supervision arrangements of NQSWs but, amongst this 'infrequent supervision' group of 32 respondents, all but one were fully registered, with one being provisionally registered, thus suggesting that the SWRB's policy was not being followed ( $\mathrm{O}^{\prime}$ Donoghue, 2019, p. 71).

Newly qualified social workers are often characterised as 'green' as in new, untested and expected to present with a mix of uncertainty and enthusiasm (Franklin, 2011). Prior to qualification, placement supervision initiates the beginning social worker into the world of practice including the experience of supervision. Field placement supervisors will have, ideally, provided a secure relationship and process in which students can be guided toward effective use of self and a developing professional identity (Davys \& Beddoe, 2010; Bogo, 2015). Social workers, supervisors and managers understand that placement is, to some extent, protected time and not 'the real world' of busy agency life; however, the segue from placement to the first professional appointment can be challenging if supervision, support and ongoing professional development opportunities are not made available (Hay, Franklin, \& Hardyment, 2012). The study reported in this article goes some way toward addressing the gap in our knowledge about the NQSW experience, particularly related to professional development and supervision.

\section{Structured support for newly qualified practitioners}

There is general agreement that newly qualified social workers are beginning practitioners and thus in need of additional support (Grant, Sheridan, \& Webb, 2016; Moorhead, Manthorpe, \& Baginsky, 2019). The experiences of NQSWs often attract descriptions such as a "baptism of fire" (Bates et al., 2010) and the transition from the protected world of placement, "a shock" (Hay et al., 2012, p. 4). In an ideal situation, NQSWs in 
Aotearoa New Zealand would have access to a structured, early-career programme such as the English "Early Professional Development" programme reported by Carpenter and colleagues (Carpenter et al., 2013; Carpenter, Shardlow, Patsios, \& Wood, 2015). This programme included dedicated time for professional development and supervision of the beginning practitioners, supporting materials for participants and supporting materials and comprehensive training for supervisors and programme coordinators. However, despite the substantial investment made in social work education, little is done in Aotearoa New Zealand to support the needs of newly qualified practitioners beyond an induction programme which may be offered by some larger employing agencies (Ballantyne et al., $2019 b$ ). For those beginning work in smaller organisations, their support needs will be met by colleagues and their supervisor (Hay et al., 2012; Hunt, Lowe, Smith, Kuruvila, \& Webber-Dreadon, 2016). Access to further professional development may be limited and continuing education is frequently available only for those willing to selffund and use personal leave. Practitioners' hopes that greater regulation of social work would lead to better resourcing for further professional development have largely remained unrealised (Beddoe, 2013, 2018). For early-career social workers however, provision of supervision has benefited from employers' obligations to meet mandatory requirements set by regulators (Beddoe, 2016). Obstacles remain for further development, notably the lack of resources in agencies, particularly non-government sector agencies and the lack of any mandate to foster post-qualifying education by the Aotearoa New Zealand regulator, as demonstrated in the paltry minimum of 20 hours contributing professional development per annum required by the SWRB (2019).

\section{Supervision for newly qualified social workers}

Supervisory support has been found to be positively linked to job satisfaction, particularly in child welfare social work (Burns, 2010), retention (Chen \& Scannapieco, 2010; Dickinson \& Painter, 2009), stress levels (Engstrom, 2017), developing professional identity (Moorhead, Bell, \& Bowles, 2016) and greater perceptions of wellbeing (Mänttäri-van der Kuip, 2014). While licensing or full registration of social workers frequently mandates minimum hours of supervision, research demonstrates that compliance with such expectations can be patchy, as research in both Australia and England reported that practitioners did not receive regular supervision (Baginsky et al., 2010; Egan, 2012; Robinson, 2013; Turner-Daly \& Jack, 2014). An English study explored the content and purpose of supervision for beginning practitioners (Manthorpe, Moriarty, Hussein, Stevens, \& Sharpe, 2013) seeking the views of NQSWs and their managers on various elements of their support and development in their jobs. A significant finding was that those with less frequent supervision were less likely to feel they had a manageable workload and felt less engaged with the job.

Space does not allow for a more detailed exploration of international research on the needs of early-career practitioners in this article but it seems clear that high quality supervision, and structured and informal team / peer support (Manthorpe et al., 2013) is vital and needs resourcing for further development and evaluation. Social work supervision provided by an experienced social worker is most appropriate at this stage and this is often offered by those who also have some managerial responsibility for the practitioner's work and thus having a dual role (Rankine, 2017; Wong \& Lee, 2015). In-house supervision may also become more managerial if it is separated from "reflective" supervision (Beddoe, 2011) as external supervision grows as a practice in social work, even for NQSWs. External supervision is defined as professional supervision of a social worker by a supervisor who is not employed in the agency where the supervisee practises (Beddoe, 2011). Often in smaller agencies, supervision is provided 
by an external supervisor and limited to the required monthly session (Rankine, 2019).

This article discusses findings regarding supervision and professional development from the second phase of the research project, "Enhancing the Readiness to Practise of Newly Qualified Social Workers". Whilst the first phase of this three-year project focussed on the content of the social work curriculum in Aotearoa New Zealand (see Ballantyne et al., 2019a), the second phase focussed on the following research question:

How well prepared are NQSWs (social workers in their two years of practice) to enter professional social work, and how is their learning being supported and enhanced in the workplace?

This phase of the study had two parts: an online survey and qualitative interviews with NQSWs and their managers / supervisors. This article draws on both the survey data and the interview content related to supervision and professional development. Ethics approval for the study was obtained from the University of Canterbury Human Ethics Committee.

\section{Method}

Participants were invited to respond to the online surveys during 2017 through social media and an invitation circulated to: a) all members of the ANZASW; and b) all social workers registered by the SWRB. Both surveys employed selection criteria. For the NQSW survey there were three selection criteria-the respondent needed to have: a) completed a recognised social work qualification from an Aotearoa New Zealand tertiary education institute within the last two years; b) been employed in a social service agency for a minimum of six months; and c) been in current paid employment as a social worker. There were a total of 195 responses to this survey, however, 71 (36\%) failed to meet the selection criteria, mostly because they had been qualified for more than two years; this resulted in a sample of 124 NQSWs. The survey was organised into the following sections: respondent demographic details; present employment position; views on workplace supervision; views on workplace induction; views on workplace learning and development; and views on respondent's qualifying degree programmes. Some respondents dropped out of the survey immediately after adding their demographic details, and these individuals were excluded leaving a final sample of 119.

The managers/ supervisors survey required respondents to have managed or supervised a NQSW within the last two years (a NQSW was defined as someone who had been qualified as a social worker for two years or less). There were a total of 193 responses to this survey; those who failed to meet the selection criteria or who dropped out after adding their demographic details were excluded, resulting in a final sample of 158 managers / supervisors. SPSS version 24 was used for the analysis of survey data; however, the cell sizes were too small on almost every test conducted. Once it was apparent that cell sizes were consistently too small, any further statistical analysis of this nature was discontinued, and the tables below report descriptive statistics.

In the qualitative component of this study, semi-structured telephone or Skype interviews were conducted over 2017-2018 with 15 newly qualified social workers in their first two years of practice and 17 managers / supervisors of newly qualified social workers recruited by an invitation that was contained in the survey. The two groups were not matched. The interview questions addressed various aspects of readiness to practise, the supports in place for NQSWs and the availability of professional development planning and opportunities. NQSWs were asked about provision, frequency of and satisfaction with supervision, appraisal, and whether they had been observed in practice.

The qualitative data were analysed using theoretical thematic analysis, described as 
"driven by the researcher's theoretical or analytic interest in the area, and...thus more explicitly analyst driven" (Braun \& Clarke, 2006, p. 84). In this study, our analysis began with an examination of responses to the main questions asked of each participant. Three of the authors coded all the transcripts using NVivo $11^{\mathrm{TM}}$ to develop node reports on our core questions. As areas of new thematic insights were identified, NVivo text searches were performed and relevant data were more finely coded by other team members. Thematic tables were produced and checked for agreement amongst the team.

\section{Participant details}

The majority of NQSW survey respondents $(55.4 \%)$ were under 35 years of age and $83.2 \%$ identified as female. Respondents were invited to select up to three ethnicities with which they identified: most identified as NZ European (64.7\%), $13.4 \%$ identified as Māori, 5\% as Chinese, 5\% as British/Irish, and smaller proportions identified with 13 other ethnicities.

Sixteen tertiary institutions in Aotearoa New Zealand which provide social work education were represented in the sample with 55.5\% attending universities, 37\% institutes of technology or polytechnics, $5 \%$ wānanga and $1.7 \%$ a private tertiary institute. Of the qualifications gained, two thirds were undergraduate $(66.4 \%)$ and one third were postgraduate $(33.6 \%)$ with $82.4 \%$ attending full-time. Half of the NQSW respondents $(50.4 \%)$ completed their social work qualification fewer than 12 months prior to the survey and the remainder qualified between 12 and 24 months prior to taking the survey $(49.6 \%)$. Almost half the NQSW respondents worked in nongovernmental agencies, almost one third in Oranga Tamariki, with $16 \%$ in District Health Boards. Most were full-time $(85.7 \%)$ with permanent contracts $(87.4 \%)$.

Almost all of the managers / professional supervisor survey respondents $(96.3 \%)$ were over the age of 35 and the majority
$(81.6 \%)$ identified as female. Respondents were invited to select up to three ethnicities with which they identified: most managers / professional supervisors identified as NZ European $(66.5 \%)$, a quarter $(24.7 \%)$ identified as Māori, 5.7\% as British/Irish, smaller proportions identified with over 18 other ethnicities. Over a third $(35.4 \%)$ of the supervisor/manager respondents worked in non-governmental agencies, a quarter (24.1\%) in Oranga Tamariki, $13.9 \%$ in district health boards, $5.7 \%$ in Iwi / Māori agencies and the remainder in other settings. One quarter worked in child protection, $13.3 \%$ community, $11.4 \%$ health and the remainder in other settings.

\section{Findings}

The findings reported here focus on questions asked both in the survey and interviews about supervision and professional development and NQSWs. Pseudonyms are used for participant quotes. Major themes identified include: variability in frequency of supervision which suggests that practice is not always well aligned with professional expectations; considerable NQSW support for external and cultural supervision, and lesser focus on professional development than is professionally desirable.

\section{Supervision frequency}

Supervision frequency was variable with many NQSWs reporting less than the optimal fortnightly supervision for NQSWs.

Internal supervision [line management] is meant to be once a month, but it happens more like once every three-ish months. It would be nice if it happened more often, but when it does happen it's also great. (Rae, NQSW)

I don't think they were competent in supervision, well-that's a big call to make. They also probably didn't have the time, so it was very much casemanagement, their priority and your supervision would come secondary to 
that and if there wasn't time then there wasn't time. And there was never time. (Ailsa, NQSW)

Not everyone was happy with what was offered and its frequency:

You're supposed to have supervision every week and you're supposed to have this and that-my supervision was case management and it wasn't every week, and my supervisor, I didn't really get a lot from, so I felt really unsupported in that sense. (Ailsa, NQSW)

Twelve items in the NQSW survey sought their views on supervision in terms of frequency, content and expectations. Table 1 shows that the majority $(87.5 \%)$ of respondents were having formal supervision meetings at least once a month with almost half $(48.8 \%)$ meeting at least fortnightly. A smaller proportion (7.6\%) were accessing supervision less than monthly. About half of respondents (see Table 2) stated that supervision frequency was less than when they commenced the job.

Table 1. Regularity of supervision

How regularly do you have formal supervision meetings?

\begin{tabular}{|l|r|c|}
\hline Response & $n$ & $\%$ \\
\hline Once a week & 27 & 22.7 \\
\hline Once every two weeks & 31 & 26.1 \\
\hline Once a month & 46 & 38.7 \\
\hline Less often & 9 & 7.6 \\
\hline Not stated & 6 & 5.0 \\
\hline Total & 119 & 100 \\
\hline
\end{tabular}

Table 2. Changes in Supervision Frequency

Has this frequency changed since you started this job?

\begin{tabular}{|l|r|r|}
\hline Response & $n$ & $\%$ \\
\hline More often now than when I started & 8 & 6.7 \\
\hline About the same as when I started & 37 & 31.1 \\
\hline Less often now than when I started & 61 & 51.3 \\
\hline Don't know yet-not been in the job long enough & 7 & 5.9 \\
\hline Not stated & 6 & 5.0 \\
\hline Total & 119 & 100 \\
\hline
\end{tabular}

\section{Focus of supervision, external and cultural supervision}

The main focus for supervision (83.2\%) identified by most NQSWs was advice and guidance on more difficult cases, although personal support (68.9\%) and case review $(61.3 \%)$ were also frequently identified. Less frequently identified were performance against targets (26.1\%), help in applying theory to practice $(33.6 \%)$ and agency policies (36.1\%) (see Table 3). Help in applying theory to practice also emerged as an aspect of supervision that most NQSWs $(62.2 \%)$ would like to see more of in their supervision sessions (see Table 4). In addition, around half wanted a lot or a little more discussion on training needs (53.8\%) and suggestions for developing reflection and self-awareness (50.5\%). Taken together these three items suggest a strong expectation that more attention is paid to the educational and developmental aspects of professional supervision.

The desirability of an educational and developmental emphasis in supervision is reflected in the comments made by NQSWs who participated in qualitative interviews. Significantly, many valued external supervision and this is explored further later. Chrissie notes the importance of having a supervisor who was trained in supervision:

In [location] I had good supervision, but then there was a changeover in employers, so then I was being supervised by somebody who didn't have their supervision qualification. She was still good, but I definitely felt the difference between that supervision and then being supervised by somebody who did. (Chrissie, NQSW)

This theme arose again in interviews with Delia, Ginny and Brent:

My current supervisor [external] is much more affirming. She affirms what I did, but still invites me to reflect. And we don't just talk about cases and 
Table 3. Aspects of Formal Supervision

What do formal supervision meetings usually cover? $(N=113)$

\begin{tabular}{|c|c|c|}
\hline \multirow{2}{*}{ Response } & \multicolumn{2}{|c|}{ Responses } \\
\hline & $n$ & $\%$ of cases \\
\hline Advice and guidance on more difficult cases & 99 & 83.2 \\
\hline Personal support, encouragement and appreciation & 82 & 68.9 \\
\hline Review of each of my cases & 73 & 61.3 \\
\hline Discussion of my training needs & 63 & 52.9 \\
\hline Suggestions for developing reflection and self-awareness & 63 & 52.9 \\
\hline Closing cases & 54 & 45.4 \\
\hline Agency policies & 43 & 36.1 \\
\hline Help in applying theoretical approaches or explanations to my practice & 40 & 33.6 \\
\hline My performance against targets & 31 & 26.1 \\
\hline Not stated & 6 & 5.0 \\
\hline
\end{tabular}

Table 4. Preference for Aspects of Supervision

Which of these aspects of supervision would you like more of, or less? ( $N=113)(Q 43)$

\begin{tabular}{|c|c|c|c|c|c|c|c|c|c|c|}
\hline \multirow{2}{*}{ Response } & \multicolumn{2}{|c|}{ Much more } & \multicolumn{2}{|c|}{ A little more } & \multicolumn{2}{|c|}{ Just the same } & \multicolumn{2}{|c|}{ Less } & \multicolumn{2}{|c|}{ Not stated } \\
\hline & $n$ & $\%$ & $n$ & $\%$ & $n$ & $\%$ & $n$ & $\%$ & $n$ & $\%$ \\
\hline $\begin{array}{l}\text { Help in applying theoretical approaches or } \\
\text { explanations to my practice }\end{array}$ & 35 & 29.4 & 39 & 32.8 & 38 & 31.9 & 0 & 0.0 & 7 & 5.9 \\
\hline Discussion of my training needs & 25 & 21.0 & 39 & 32.8 & 46 & 38.7 & 1 & 0.8 & 8 & 6.7 \\
\hline $\begin{array}{l}\text { Suggestions for developing reflection and } \\
\text { self-awareness }\end{array}$ & 24 & 20.2 & 36 & 30.3 & 50 & 42.0 & 1 & 0.8 & 8 & 6.7 \\
\hline Advice and guidance on more difficult cases & 22 & 18.5 & 30 & 25.2 & 58 & 48.7 & 0 & 0.0 & 9 & 7.6 \\
\hline Personal support, encouragement and appreciation & 18 & 15.1 & 34 & 28.6 & 60 & 50.4 & 0 & 0.0 & 7 & 5.9 \\
\hline Agency policies & 17 & 14.3 & 25 & 21.0 & 63 & 52.9 & 5 & 4.2 & 9 & 7.6 \\
\hline My performance against targets & 12 & 10.1 & 19 & 16.0 & 69 & 58.0 & 9 & 7.6 & 10 & 8.4 \\
\hline Review of each of my cases & 8 & 6.7 & 30 & 25.2 & 68 & 57.1 & 4 & 3.4 & 9 & 7.6 \\
\hline Closing cases & 5 & 4.2 & 20 & 16.8 & 81 & 68.1 & 3 & 2.5 & 10 & 8.4 \\
\hline
\end{tabular}

about what I'm currently doing, she's helped me to think a lot more about my core values and where those come from, and why I practise the way that I do. And what in my environment and what in my upbringing has made me the way I am and made me think about things the way I do. Which has been very beneficial, I'd say not just in my professional life, but also in my personal life. (Delia, NQSW)

A strong focus on learning and to some extent the inclusion of theory in the supervision space, with the supervisor having a broad focus:

So, we can talk about theories and what guides my practice, and also look at critically analysing things. So, if something's struck a chord with me, or something's upset me or something's bothered me, she's really good at looking at why and how do we overcome that, and what does that look for your practice. And I can be completely honest if I've done something that's questionable, I can talk to her about that and what I should 
do. It's fantastic, I always like going to supervision. (Ginny, NQSW)

Well I'm very much satisfied because we have, it covers all aspects, like our personal wellbeing, self-care. He's asking how is your health, family, everything, there's a personal bond. The second part is the case load, any advice or anything that is required, there's a case discussion. And any other thing, any other thing regarding learning, if I say I'm not comfortable dealing with trauma, or trauma-informed practice or that sort of thing, then as soon as training comes, I'll be sent for that. So, all supervision, personal aspects and professional aspects are discussed so I am very happy. (Brent, NQSW)

As noted in the literature, internal supervision (Beddoe, 2011; Rankine, 2017) can be limited by issues of power and workplace dynamics. The tensions of having supervision with a supervisor holding dual roles (Wong \& Lee, 2014) were illustrated by interview participants' description of their experience:

Well the thing is in big organisations, when you've got an internal supervisor who is sometimes your manager or has some sort of oversight of your job, their thoughts can be clouded. So I've had an internal supervisor, where you could see it all over her face that she didn't like her job, and I'd go into supervision and she would sit there and go "oh I've had a big day" and it's kind of like, oh well it's not about you it's about me right now. (Chrissie, NQSW)
Trust and the security of feeling in control of sharing personal challenges, noted by Egan, Maidment, and Connolly (2017) were highly significant for these participants. Ailsa was hoping to be able to have external supervision to avoid this dynamic, while Sally also emphasised how trust enhanced their willingness to be honest in their external supervision:

External supervision would be really, really awesome. ...It also removes a whole lot of the workplace dynamic, because whoever you're talking to isn't part of that, you can be really open and honest with...what you're struggling with. (Ailsa, NQSW)

They let me know that I'll have external supervision, which is really great, because it's really hard having internal supervision because you kind of have to trust that what you tell your supervisor doesn't go anywhere, but you might not bring up an issue with them if you wanted to, like with your colleagues or your management, because you're aware that they know them and they're involved with them. So, it'll be great to have that external supervision where I can just speak about anything and know that it's not really going to go anywhere. (Sally, NQSW)

Table 5 explores respondents' views on the extent to which supervision helps them to undertake certain professional tasks and improving professional practice is the most highly rated with over three quarters $(79.9 \%)$

Table 5. Improvement Under Supervision

To what extent do you feel your supervision helps you to improve?

\begin{tabular}{|c|c|c|c|c|c|c|c|c|c|c|}
\hline \multirow{2}{*}{ Response } & \multicolumn{2}{|c|}{ A great deal } & \multicolumn{2}{|c|}{ A little } & \multicolumn{2}{|c|}{ Not much } & \multicolumn{2}{|c|}{ Not at all } & \multicolumn{2}{|c|}{ Not stated } \\
\hline & $\mathbf{n}$ & $\%$ & $\mathbf{n}$ & $\%$ & $\mathbf{n}$ & $\%$ & $\mathbf{n}$ & $\%$ & $\mathbf{n}$ & $\%$ \\
\hline Improve your professional practice & 59 & 49.6 & 36 & 30.3 & 10 & 8.4 & 6 & 5.0 & 8 & 6.7 \\
\hline Maintain professional boundaries with service users & 43 & 36.1 & 43 & 36.1 & 16 & 13.4 & 8 & 6.7 & 8 & 6.7 \\
\hline Cope with stress & 40 & 33.6 & 47 & 39.5 & 14 & 11.8 & 10 & 8.4 & 8 & 6.7 \\
\hline Work with the cultural issues in your practice & 38 & 31.9 & 33 & 27.7 & 25 & 21.0 & 14 & 11.8 & 9 & 7.6 \\
\hline Prioritise your workload & 33 & 27.7 & 49 & 41.2 & 23 & 19.3 & 5 & 4.2 & 9 & 7.6 \\
\hline
\end{tabular}


stating that supervision helps a great deal or a little.

Supervision was found to be not much, or not at all helpful by $32.8 \%$ respondents in relation to work with cultural issues and, somewhat surprisingly, by $23.5 \%$ with regard to prioritising workload.

What was particularly valued by interview participants was the reflective nature of external supervision:

Internally you do often get caught up talking about the clients as opposed to where you are at as a professional and as a worker. It's good to have that internal to keep on top of that caseload, but external was where I got most of my learning from as well. [External] was way more reflective. It was often brought back to who am I as a practitioner, not just the worker, the social worker. (Chrissie, NQSW)

We also asked questions about cultural supervision and one quarter of NQSW respondents $(25.2 \%)$ stated they had received cultural supervision or kaupapa Māori supervision, to support their work with Māori and / or other cultural groups. Of those who had received cultural supervision, the overwhelming majority (90\%) found it very, or quite, helpful. In addition, of those who had not received cultural supervision, the majority $(72.3 \%)$ agreed that it is something that would be helpful to them.

The finding that routine supervision is less helpful with cultural issues, taken together with the strong NQSW support for cultural supervision (amongst both the minority who accessed it and the majority who have not), suggests that agencies should consider reviewing access to cultural supervision for NQSWs. One of the NQSW interviewees expressed this point very clearly:

I guess the one thing I've been thinking about recently is that [my supervisor is]
Pākehā, I'm Pākehā, half of my clients are Māori. Actually, it'd be really good to have someone who can speak to best practice with Māori and what that looks like. And she's not terrible at that, but I'm just starting to think actually it would probably be better if I had a Māori social worker. (Becky, NQSW)

\section{Professional development other than supervision}

Since social work practice is essentially a relational and interpersonal practice that most often occurs in places out of the view of supervisors (for example, in closed offices and family homes) then the observation of practice by a supervisor can be a good source of information about a practitioner's strengths and areas for development (Davys \& Beddoe, 2015). In field education in Aotearoa New Zealand there is an expectation that students will be observed on placement regularly, although it is not a requirement of the SWRB and nothing is reported about the ongoing observation of qualified practitioners. We asked NQSWs to report how frequently their supervisor observed their practice and the results (see Table 6) indicate clearly that this is not a routine part of supervisory practice: around a quarter stated that they were observed at least once a month $(24.3 \%)$, another quarter less often $(23.5 \%)$ and approaching half $(46.2 \%)$ stated their practice had never been observed.

Table 6. Frequency of observation of practice

How often does your supervisor actually observe your practice?

\begin{tabular}{|l|c|c|}
\hline Response & $n$ & $\%$ \\
\hline About once a week & 6 & 5.0 \\
\hline About once every two weeks & 11 & 9.2 \\
\hline About once a month & 12 & 10.1 \\
\hline Less often & 28 & 23.5 \\
\hline Never & 55 & 46.2 \\
\hline Not stated & 7 & 5.9 \\
\hline Total & 119 & 99.9 \\
\hline
\end{tabular}


Collaborative observations of practice, with a peer or supervisor, can provide useful information to feed into annual performance appraisals as well as providing formative feedback (Davys \& Beddoe, 2015). Asked whether they had had a formal appraisal by their supervisor over half $(54.6 \%)$ stated they had not. However, in response to question 50, asking: How well do you think your supervisor rates your performance so far in your present $j o b$ ?, almost all considered that they were rated either very highly (32.8\%) or quite highly $(58.8 \%)$ by their supervisor. Furthermore, $81.5 \%$ considered this assessment of their performance to be a fair assessment.

There are other forms of learning and development activities, such as working alongside more experienced peers or group sessions for newly qualified workers, that an employer can set up for NQSWs. Table 7 shows responses to seven different types of learning and development and that around half of participants had access to shadowing of a more experienced social work colleague (54.6\%), peer supervision (51.3\%) and co-working a case with more experienced social work colleague $(47.9 \%)$. Group sessions for NQSWs were far less commonly reported.

As shown in Table 8, less than half of respondents $(47.9 \%)$ stated that they had a professional development plan (PDP) in place, but for those who did, most had discussed it with their supervisor $(75.4 \%)$ and the majority stated that the supervisor was helping them to implement the plan (61.4\%). In the English study, in a context where personal development planning had a strong policy emphasis, a higher proportion of NQSWs had a PDP (61\%), yet only $41 \%$ had discussed it with a line manager and only 35\% agreed that a line manager helped them to implement the plan (Manthorpe et al, 2013).

Support from supervisors and line managers was crucial to the effectiveness of personal career planning yet, as noted, earlier in Table 4, approximately $40 \%$ of NQSWs wanted more opportunity to discuss their learning needs with supervisors. Where this did occur, it was valued by NQSWs. One participant highlighted the value of their agency's commitment to professional development planning:

We have the standard personal development plan, which most workplaces will have, but they've put a lot of value into ... what learning you want to get and what will help you to continue your learning ... To give meaning to your work, and to what you're doing and then yourself. And the conversations that we have, even just with the manager there, we were in the car the other day and ... I just know how much he values [learning] and then how much in the organisation that is a really strong value. (Ailsa NQSW)

Table 7. Learning and devdelopment in the workplace

Have you had experience of any of the following, in your current job? $(n=97)$

\begin{tabular}{|c|c|c|}
\hline \multirow{2}{*}{ Response } & \multicolumn{2}{|c|}{ Responses } \\
\hline & $n$ & $\%$ of cases \\
\hline Shadowing of a more experienced social work colleague - from your own team & 65 & 54.6 \\
\hline Peer supervision - when several social workers from your team share experiences with your professional supervisor & 61 & 51.3 \\
\hline Co-working a case with more experienced social work colleague/s & 57 & 47.9 \\
\hline Shadowing a colleague - from a different profession & 28 & 23.5 \\
\hline Shadowing of a more experienced social work colleague - from a different team & 27 & 22.7 \\
\hline $\begin{array}{l}\text { Group session/s for newly-qualified social workers (including action learning sets or support groups)—within your } \\
\text { own team }\end{array}$ & 18 & 15.1 \\
\hline $\begin{array}{l}\text { Group session/s for newly-qualified social workers (including action learning sets or support groups)_involving } \\
\text { NQSW from other teams or agencies }\end{array}$ & 9 & 7.6 \\
\hline
\end{tabular}


The supervisors / managers were also asked a survey question about the kinds of learning and development activities undertaken by employers and their views on how well this was done. As can be seen from Table 9, most employers identified that they did the following well: taking students on placement (63.9\%); provide "shadowing" for social work students (55.1\%); recruiting newly qualified social workers from among those having undertaken a student placement in your organisation $(53.2 \%)$ and providing closer supervision for newly qualified social workers than for more experienced recruits $(50 \%)$.

Of the items that respondents thought their agencies could do more or better, the highest rated were providing induction programme for newly qualified social workers (40.5\%); qualified social workers on your staff giving (occasional) lectures/seminars to students on social work programmes $(37.3 \%)$ and closer supervision
Table 8. Professional developmetn plan

Do you have a Professional Development Plan (PDP)?

\begin{tabular}{|l|c|c|}
\hline Response & $n$ & $\%$ \\
\hline Yes & 57 & 47.9 \\
\hline No & 50 & 42.0 \\
\hline Not stated & 12 & 10.1 \\
\hline Total & 119 & 100 \\
\hline
\end{tabular}

for newly qualified social workers than for more experienced recruits $(36.1 \%)$.

The supervisors' and managers' interviews revealed great variability in the perceptions of support available for NQSWs, with agencies and supervisors often providing a good support system:

We also have things such as fortnightly team meetings, and there is a practice component to all of that. We have regular training. Everyone has a training budget,

Table 9. Employer activities

Employer activities as reported by managers (Q16)

\begin{tabular}{|c|c|c|c|c|c|c|c|c|}
\hline \multirow[t]{2}{*}{ Response } & \multicolumn{2}{|c|}{$\begin{array}{c}\text { We don't do this } \\
\text { at all }\end{array}$} & \multicolumn{2}{|c|}{ We do this well } & \multicolumn{2}{|c|}{$\begin{array}{l}\text { We could do this } \\
\text { more, or better }\end{array}$} & \multicolumn{2}{|c|}{ Not stated } \\
\hline & $n$ & $\%$ & $n$ & $\%$ & $n$ & $\%$ & $n$ & $\%$ \\
\hline $\begin{array}{l}\text { Sponsor unqualified staff to qualify as social workers } \\
\text { by paying their salaries while they are studying }\end{array}$ & 77 & 48.7 & 32 & 20.3 & 32 & 20.3 & 17 & 10.8 \\
\hline Encourage staff to gain a qualification in supervision & 39 & 24.7 & 54 & 34.2 & 49 & 31.0 & 16 & 10.1 \\
\hline $\begin{array}{l}\text { Qualified social workers on your staff giving } \\
\text { (occasional) lectures/seminars to students on social } \\
\text { work programmes }\end{array}$ & 32 & 20.3 & 49 & 31.0 & 59 & 37.3 & 18 & 11.4 \\
\hline $\begin{array}{l}\text { Provide further training opportunities to qualified social } \\
\text { workers }\end{array}$ & 16 & 10.1 & 75 & 47.5 & 51 & 32.3 & 16 & 10.1 \\
\hline $\begin{array}{l}\text { Recruit newly qualified social workers from among } \\
\text { those having undertaken a student placement in your } \\
\text { organisation }\end{array}$ & 15 & 9.5 & 84 & 53.2 & 42 & 26.6 & 17 & 10.8 \\
\hline Provide "shadowing" for social work students & 14 & 8.9 & 87 & 55.1 & 38 & 24.1 & 19 & 12.0 \\
\hline $\begin{array}{l}\text { Induction programme for newly qualified social } \\
\text { workers }\end{array}$ & 12 & 7.7 & 66 & 41.8 & 64 & 40.5 & 16 & 10.1 \\
\hline Take social work students on placement & 12 & 7.7 & 101 & 63.9 & 26 & 16.5 & 19 & 12.0 \\
\hline $\begin{array}{l}\text { Limited initial caseload for newly qualified social } \\
\text { workers }\end{array}$ & 11 & 7.0 & 77 & 48.7 & 53 & 33.5 & 17 & 10.8 \\
\hline $\begin{array}{l}\text { Closer supervision for newly qualified social workers } \\
\text { than for more experienced recruits }\end{array}$ & 6 & 3.8 & 79 & 50.0 & 57 & 36.1 & 16 & 10.1 \\
\hline
\end{tabular}


it is $\$ 1200$, and the supervisor works with them [on] a development plan ... And that's part of their induction as well, is going out and meeting all the different agencies, picking up the resources and all of that. So for the first year we're working to give them the knowledge and make sure that they can reflect and observe ... so that in the second year they're flying more by themselves (Davina, SupMan).

So they get a two-week orientation, as opposed to some other places, you're not just shown your desk and here's your caseload and off you go. They get to meet and greet people and find out what in-house players' roles are. For the first two to three months they are encouraged to do quite a bit of networking if they haven't already established some networks. ...Usually somebody is available to kind of be, not a designated buddy and maybe that's something we need to consider. But people are available to pick their brains... And also usually they're supervised (Sam SupMan)

Some NQSWs, however, were less enthusiastic

I definitely felt my boss ... wasn't that gracious towards new graduates. She didn't really have a lot of time for people who didn't know what she was talking about straight away, especially in terms of she was very knowledgeable about [name of ward] and I'm not obviously when I come straight from uni with not a lot experience, so that was difficult. (Sally NQSW)

NQSWs reported that they did not only rely on their supervisors for support and guidance and that learning from peers and more experienced colleagues was very highly valued:

At my workplace actually, it's very, very generous, not only my buddy, but anybody I can approach. Anybody, all of the newbies can approach any of the senior social workers and they are all more than ready to help us, and that's really helping us. (Brent NQSW)

...but also having social worker and counselling colleagues there as support to learn off and they're very good at wanting to help all the time. ... And there's quite a few people that are social work trained around here as well, so it means that I can just run things past them if I need to. We've got quite a few people who used to work at Child, Youth and Family, so because I'm kind of working in that environment now I can go and pick their brains about it as well. (Teri NQSW)

Always learning from colleagues, so even through peer supervision and things like that. Always learning all the time, so that's really awesome. (Josie NQSW)

NQSWs were asked to rate the extent to which they received help and support from their workplace to improve on six factors. Table 10 indicates that most participants received a great deal or a little support in relation to all six factors. Whilst this is reassuring, it is also worthy of note that 2 out of 10 NQSWs considered that they had not much or no help and support in relation to feedback from service users and carers on your practice $(22.6 \%)$ and the accuracy and analytical insights of your case assessments (20.1\%).

Adding this to the lack of direct observation of practice and formal appraisals does raise concerns about inputs to their professional development.

\section{Conclusions}

The study findings demonstrate a patchy provision of support for NQSWs development, which is perhaps unsurprising given the lack of any clearly mandated expectations. Agencies employing NQSWs may need to check that their practice of supervision in the first two years is better aligned with the recommendations and expectations of professional bodies. While 
Table 10. Support for practice improvement

How much appropriate help and support have you received in your current workplace for improving your practice?

\begin{tabular}{|c|c|c|c|c|c|c|c|c|c|c|}
\hline \multirow[t]{2}{*}{ Response } & \multicolumn{2}{|c|}{$\begin{array}{l}\text { A great deal } \\
\text { of help and } \\
\text { support }\end{array}$} & \multicolumn{2}{|c|}{$\begin{array}{l}\text { A little help } \\
\text { and support }\end{array}$} & \multicolumn{2}{|c|}{$\begin{array}{l}\text { Not much help } \\
\text { and support }\end{array}$} & \multicolumn{2}{|c|}{$\begin{array}{l}\text { No help and } \\
\text { support at all }\end{array}$} & \multicolumn{2}{|c|}{ Not stated } \\
\hline & $\mathbf{n}$ & $\%$ & $\mathbf{n}$ & $\%$ & $\mathbf{n}$ & $\%$ & $\mathbf{n}$ & $\%$ & $\mathbf{n}$ & $\%$ \\
\hline The overall quality of your practice & 36 & 30.3 & 53 & 44.5 & 9 & 7.6 & 4 & 3.4 & 17 & 14.3 \\
\hline $\begin{array}{l}\text { Your choice of suitable interventions more likely } \\
\text { to lead to better outcomes for the service users } \\
\text { and carers on your caseload }\end{array}$ & 32 & 26.9 & 50 & 42.0 & 14 & 11.8 & 6 & 5.0 & 17 & 14.3 \\
\hline Your personal confidence & 32 & 26.9 & 50 & 42.0 & 13 & 10.9 & 8 & 6.7 & 16 & 13.4 \\
\hline Your own professional abilities & 30 & 25.2 & 55 & 46.2 & 15 & 12.6 & 3 & 2.5 & 16 & 13.4 \\
\hline $\begin{array}{l}\text { The accuracy and analytical insights of your } \\
\text { case assessments }\end{array}$ & 29 & 24.4 & 49 & 41.2 & 18 & 15.1 & 6 & 5.0 & 17 & 14.3 \\
\hline $\begin{array}{l}\text { Feedback from service users and carers on } \\
\text { your practice }\end{array}$ & 25 & 21.0 & 49 & 41.2 & 16 & 13.4 & 11 & 9.2 & 18 & 15.1 \\
\hline
\end{tabular}

half of NQSWs were supervised at least once every two weeks, the remainder were supervised monthly or less frequently. Whilst monthly supervision is the SWRB requirement for all social workers, this seems seriously infrequent for NQSWs given the evidence of supervision impacting on professional identity (Moorhead, Bell, \& Bowles, 2016) confidence, satisfaction, stress (Engstrom, 2017) and intention to remain (Burns, 2010; Chen \& Scannapieco, 2010; Dickinson \& Painter, 2009; Manthorpe et al., 2013) and wellbeing (Mänttäri-van der Kuip, 2014). In the majority of cases, the primary focus of supervision was on advice and guidance on difficult cases, although personal support and case review were also frequently identified. In the interviews, NQSWs with external supervision reported greater access to reflective supervision.

NQSWs wanted more attention paid to the educational and developmental aspects of professional supervision including: help in applying theory to practice; more discussion on training needs; and suggestions for developing reflection and self-awareness. In addition, the finding that routine supervision is less helpful with cultural issues, taken together with strong NQSW support for cultural supervision suggests that agencies should consider reviewing access to cultural supervision for NQSWs. In the interviews, there was strong support for external supervision for the reasons usually cited in the literature: trust, openness and distance from the dynamics of the dual role of supervisor/manager (Rankine, 2017; Wong \& Lee, 2014). Trust and feeling safe are important aspects of a positive supervision relationship (Egan, Maidment, \& Connolly, 2017) and perhaps more so in the early years.

As noted above, most NQSWs were very positive about professional support from colleagues and the friendliness of other staff in the workplace. There was agreement on teamwork. Managers / supervisors were very positive about NQSW team contributions. NQSWs highly valued learning from peers and more experienced colleagues. Around half of NQSWs stated they had access to peer supervision, and opportunities to co-work or to shadow more experienced colleagues. Findings indicate clearly that the observation of practice was either very infrequent or entirely absent from the professional supervision of NQSWs. Given the value of these opportunities there is clearly scope for employers to consider making peer support, external supervision and observation of practice more widely available. The absence of any significant professional leadership for the development of any mandated beginning 
practitioner programme will continue to be an obstacle to change.

Accepted 13 March 2020

Published 1 August 2020

\section{References}

Aotearoa New Zealand Association of Social Workers. (2015). Supervision policy. Christchurch, NZ: Author.

Baginsky, M., Moriarty, J., Manthorpe, J., Stevens, M. MacInnes, T., \& Nagendran, T. (2010). Social workers' workload survey messages from the frontline. Children's Workforce Development Council, and King's College London. Retrieved from https://www.bl.uk/collectionitems/social-workers-workload-survey-messages-fromthe-frontline

Ballantyne, N., Beddoe, L., Hay, K., Maidment, J., Walker, S., \& Ngan, L. (2019a). Enhancing the readiness to practise of newly qualified social workers in Aotearoa New Zealand (Enhance R2P)-Report on phase one: The social work curriculum. Wellington, NZ: Ako Aotearoa.

Ballantyne, N., Beddoe, L., Hay, K., Maidment, J., Walker, S., \& Mayhew, Z. (2019b). Enhancing the readiness to practise of newly qualified social workers in Aotearoa New Zealand (Enhance R2P)-Report on phase two: The readiness to practise of NQSWs. Wellington, NZ: Ako Aotearoa.

Ballantyne, N., Beddoe, L., Hay, K., Maidment, J., Walker, S., \& Merriman, C. (2019c). Enhancing the readiness to practise of newly qualified social workers in Aotearoa New Zealand (Enhance R2P)—Report on phase three: The Professional Capabilities Framework. Wellington, NZ: Ako Aotearoa.

Bates N., Immins T., Parker J., Keen S., Rutter L., Brown K., \& Zsigo S. (2010) "Baptism of fire": The first year in the life of a newly qualified social worker. Social Work Education, 29(2), 152-170.

Beddoe, L. (2011). External supervision in social work: Power, space, risk, and the search for safety. Australian Social Work, 65(2), 197-213. doi:10.1080/031240 $7 \times .2011 .591187$

Beddoe, L. (2013). Continuing education, registration and professional identity in New Zealand social work. International Social Work, 58(1), 165-174. doi:10.1177/0020872812473139

Beddoe, L. (2016). Supervision in social work in Aotearoa New Zealand: Challenges in changing contexts. The Clinical Supervisor, 35(2), 156-174. doi:10.1080/073252 23.2016.1217497

Beddoe, L. (2018). Social work education in Aotearoa New Zealand: Building a profession. Practice, 30(4), 305-320. doi:10.1080/09503153.2018.1478955

Bogo, M. (2015). Field education for clinical social work practice: Best practices and contemporary challenges. Clinical Social Work Journal, 43, 317-324. doi:10.1007/ s10615-015-0526-5

Braun, V., \& Clarke, V. (2006). Using thematic analysis in psychology. Qualitative Research in Psychology, 3(2), 77-101. doi:10.1191/1478088706qp063oa
Burns, K. (2010). "Career preference", "transients" and "converts": A study of social workers' retention in child protection and welfare. British Journal of Social Work, 41(3), 520-538.

Carpenter, J., Patsios, D., Wood, M., Platt, D., Shardlow, S., Mclaughlin, H., . . Blewett, J. (2013). Early Professional Development Pilot Programme (First cohort 2009 to 2011): Final evaluation report. London, UK: Department for Education.

Carpenter, J., Shardlow, S. M., Patsios, D., \& Wood, M. (2015). Developing the confidence and competence of newly qualified child and family social workers in England: Outcomes of a national programme. British Journal of Social Work, 45(1), 153-176. doi:10.1093/ bjsw/bct106

Chen, S., \& Scannapieco, M. (2010). The influence of job satisfaction on child welfare worker's desire to stay: An examination of the interaction effect of self-efficacy and supportive supervision. Children and Youth Services Review, 32(4), 482-486.

Davys, A., \& Beddoe, L. (2010). Best practice in professional supervision: A guide for the helping professions. London, UK: Jessica Kingsley.

Davys, A. M., \& Beddoe, L. (2015). "Going live": An exploration of models of peer, supervisor observation and observation for assessment. Practice, 28(1), 3-20. doi:10.1080/09503153.2015.1053857

Dickinson, N. S., \& Painter, J. S. (2009). Predictors of undesired turnover for child welfare workers. Child Welfare, 88(5), 187-208.

Egan, R. (2012). Australian social work supervision practice in 2007. Australian Social Work, 65(2), 171-184. doi:10. 1080/0312407x.2011.653575

Egan, R., Maidment, J., \& Connolly, M. (2017). Trust, power and safety in the social work supervisory relationship: Results from Australian research. Journal of Social Work Practice, 31(3), 307-321. doi:10.1080/02650533.2016. 1261279

Engstrom, S. (2017). Interpersonal justice: the importance of relationships for child and family social workers. Journal of Social Work Practice, 33(1), 41-53. doi:10.1080/0265 0533.2017.1400957

Franklin, L. D. (2011). Reflective supervision for the green social worker: Practical applications for supervisors. The Clinical Supervisor, 30(2), 204-214. doi:10.1080/073252 23.2011.607743

Grant, S., Sheridan, L., \& Webb, S. A. (2016). Newly qualified social workers' readiness for practice in Scotland. British Journal of Social Work, 47(2), 487-506. doi:10.1093/ bjsw/bcv146

Hay, K., Franklin, L., \& Hardyment, A. (2012). From student to employee: A conversation about transition and readiness for practice in a statutory social work organisation. Social Work Now, 50, 2-9.

Hunt, S., Lowe, S., Smith, K., Kuruvila, A., \& WebberDreadon, E. (2016). Transition to professional social work practice: The initial year. Advances in Social Work and Welfare Education, 18(1), 55-71.

Mänttäri-van der Kuip, M. (2014). The deteriorating workrelated well-being among statutory social workers in a rigorous economic context. European Journal of Social Work, 17(5), 672-688. 
Manthorpe, J., Moriarty, J., Hussein, S., Stevens, M., \& Sharpe, E. (2013). Content and purpose of supervision in social work practice in England: Views of newly qualified social workers, managers and directors. British Journal of Social Work, 45(1), 52-68. doi:10.1093/bjsw/ bct102

Moorhead, B., Bell, K., \& Bowles, W. (2016). Exploring the development of professional identity with newly qualified social workers. Australian Social Work, 69(4), 456-467. doi:10.1080/0312407X.2016.1152588

Moorhead, B., Manthorpe, J., \& Baginsky, M. (2019). An examination of support and development mechanisms for newly qualified social workers across the UK: Implications for Australian social work. Practice, 1-15. doi:10.1080/09503153.2019.1660314

O'Donoghue, K. B. (2019). The supervision of registered social workers in Aotearoa New Zealand: A national survey. Aotearoa New Zealand Social Work, 31(3), 59-77. doi:10.11157/anzswj-vol31iss3id648

Rankine, M. (2017). Making the connections: A practice model for reflective supervision. Aotearoa New Zealand Social Work, 29(3), 13. doi:10.11157/anzswj-vol29iss3id377

Rankine, M. (2019). The internal/external debate: The tensions within social work supervision. Aotearoa New Zealand Social Work, 31(3), 14. doi:10.11157/ anzswj-vol31iss3id646

Robinson, K. (2013). Supervision found wanting: Experiences of health and social workers in non-government organisations working with refugees and asylum seekers. Practice, 25(2), 87-103. doi:10.1080/0950315 3.2013.775238

Social Workers Registration Board. (2018). Supervision expectations for registered social workers: Policy statement. Wellington, NZ: Author. Retrieved from http:// swrb.govt.nz/about-us/policies/

Social Workers Registration Board. Continuing Professional Development. (2019). (online policy). Wellington, NZ: Author. Retrieved from https://swrb.govt.nz/socialworkers/practising/continuing-professional-development/

Turner-Daly, B., \& Jack, G. (2014). Rhetoric vs. reality in social work supervision: The experiences of a group of child care social workers in England. Child \& Family Social Work, 22(1), 36-46. doi:10.1111/cfs.12191

Wong, P. Y. J., \& Lee, A. E. Y. (2015). Dual roles of social work supervisors: Strain and strengths as managers and clinical supervisors. China Journal of Social Work, 8(2), 164-181. doi:10.1080/17525098.2015.1039168 